\title{
Roman Fortress Pitiunt: 3D-Reconstruction of the Monument Based on the Materials of Archaeological Research and Geological Paleoreconstructions
}

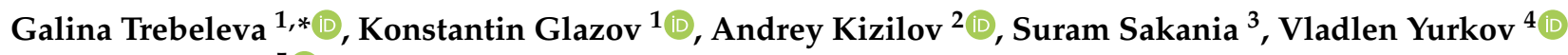 \\ and Gleb Yurkov ${ }^{5}$ (i) \\ 1 Institute of Archaeology, Russian Academy of Sciences, 117292 Moscow, Russia; paradoxsochi@yandex.ru \\ 2 Federal Research Centre, the Subtropical Scientific Centre of the Russian Academy of Sciences, \\ 354000 Sochi, Russia; kiziloff2014@mail.ru \\ 3 Gulia Abkhaz Institute for Humanitarian Research, Academy of Sciences of Abkhazia, \\ Suhum 384900, Georgia; abigi@rambler.ru \\ 4 Secondary School 171, 119270 Moscow, Russia; vladlen.yurkov.v@mail.ru \\ 5 N.N. Semenov Federal Research Center for Chemical Physics, Russian Academy of Sciences, \\ 119334 Moscow, Russia; ygy76@mail.ru \\ * Correspondence: g_gis@mail.ru
}

check for

updates

Citation: Trebeleva, G.; Glazov, K.; Kizilov, A.; Sakania, S.; Yurkov, V.; Yurkov, G. Roman Fortress Pitiunt: 3D-Reconstruction of the Monument Based on the Materials of Archaeological Research and Geological Paleoreconstructions. Appl. Sci. 2021, 11, 4814. https:// doi.org/10.3390/app11114814

Academic Editors: Mauro Lo Brutto and Valentina Alena Girelli

Received: 29 March 2021

Accepted: 20 May 2021

Published: 24 May 2021

Publisher's Note: MDPI stays neutra with regard to jurisdictional claims in published maps and institutional affiliations.

Copyright: (c) 2021 by the authors. Licensee MDPI, Basel, Switzerland. This article is an open access article distributed under the terms and conditions of the Creative Commons Attribution (CC BY) license (https:/ / creativecommons.org/licenses/by/ $4.0 /)$.

\begin{abstract}
The present study examined the references in the works of ancient authors to the ancient city and the Roman fortress Pitiunt, the geological aspects of the formation of the coastline in the Pitsunda Cape area in the first centuries AD and the results of archaeological research of the monument performed from 1952 to 1974 . The creation of the 3D reconstruction of the exterior of the Pitiunt fortress during its prosperity in the IV century $\mathrm{AD}$, along with the churches which were the first monuments of religious architecture in northwestern Colchis (northwestern Colchis comprises parts of the territory of modern Russia, Georgia and Abkhazia) was carried out based on the excavation plans and the principles of fortification and temple architecture that were accepted in the late Roman times, paying special attention to the geological paleoreconstructions.
\end{abstract}

Keywords: Pitiunt fortress; Pontic limes; roman time; 3D reconstruction; geological paleoreconstruction

\section{Introduction}

In the recent decade, 3-D technologies have been widely used in archeology in order to protect historical and cultural heritage, aiming at creation of 3D models of various archaeological sites. The purpose of 3D models is not only to visualize and popularize scientific knowledge but also to preserve and present scientific information. Methodologically, two main lines can be noted: fixing the modern condition of archaeological objects, site or exhibits and reconstructing their original appearance. For the first line, various methods, for example, photogrammetry [1-7], laser scanning (TLS) [8,9], LiDAR technology [10], etc., are applied when it is necessary to determine and investigate the present 3-D geometry of an object, i.e., to obtain a 3-D image of the current state of an archaeological site or exhibit with the aim of creating a virtual exhibition. The second line comprises the creation of 3-D geometry of a lost or destroyed site based on materials from archaeological research, historical descriptions and analysis of surviving analogies [11-18]. As the output of both described methods, 3-D models used to create virtual reality (VR) in scientific, educational and exhibition activities can be obtained $[8,9,19]$. This is consistent with the provisions of the London Charter [20]

The aims, methods and dissemination plans of computer-based visualization should reflect consideration of how such work can enhance access to cultural heritage that is otherwise inaccessible due to health and safety, disability, economic, political or environmental 
reasons or because the object of the visualization is lost, endangered, dispersed or has been destroyed, restored or reconstructed.

The present study is an example of the second line with the purpose not only to demonstrate the historical site but also to carry out historical research, which means studying narrative sources, archival data, doing exploration, reading the literature on similar fortresses and types of military camps [10-18] and kanabs and analyzing reconstruction paleolandscape [21]. The present work required in-depth analysis and support of each statement in accordance with the "principle of transparency" to eliminate or minimize speculative conclusions and decisions.

The Pitiunt Fortress, situated in the modern city of Pitsunda (Abkhazia), along with the other fortifications of the Roman Empire such as Apsar, Phasis and Sebastopolis, is one of the most significant classical monuments of the Roman expansion on the Eastern Black Sea coast. The state of modern preservation compares to that of the Apsar fortress which underwent several periods of reconstruction and was maintained by the Ottoman Empire until 1878, resulting in its present perfect condition. However, the Pitiunt fortress, unlike Apsar, lost its significance after the 6th century AD, when it was abandoned by the garrison, and since then has not been restored. In this regard, at present, the fortress can be described as extended remnants of walls and foundations of internal structures, overgrown with subtropical vegetation, which conceal the greatness of the site (Figure 1). Meanwhile, the Pitiunt fortress figured prominently in the chain of Roman fortifications in the Eastern Black Sea region in the first centuries AD, and therefore, its archaeological study is of great interest for the historical and archeological science. A 3D reconstruction of the exterior of the fortress during its prosperity, 4th century AD, will highlight the significance of the fortress at that time.
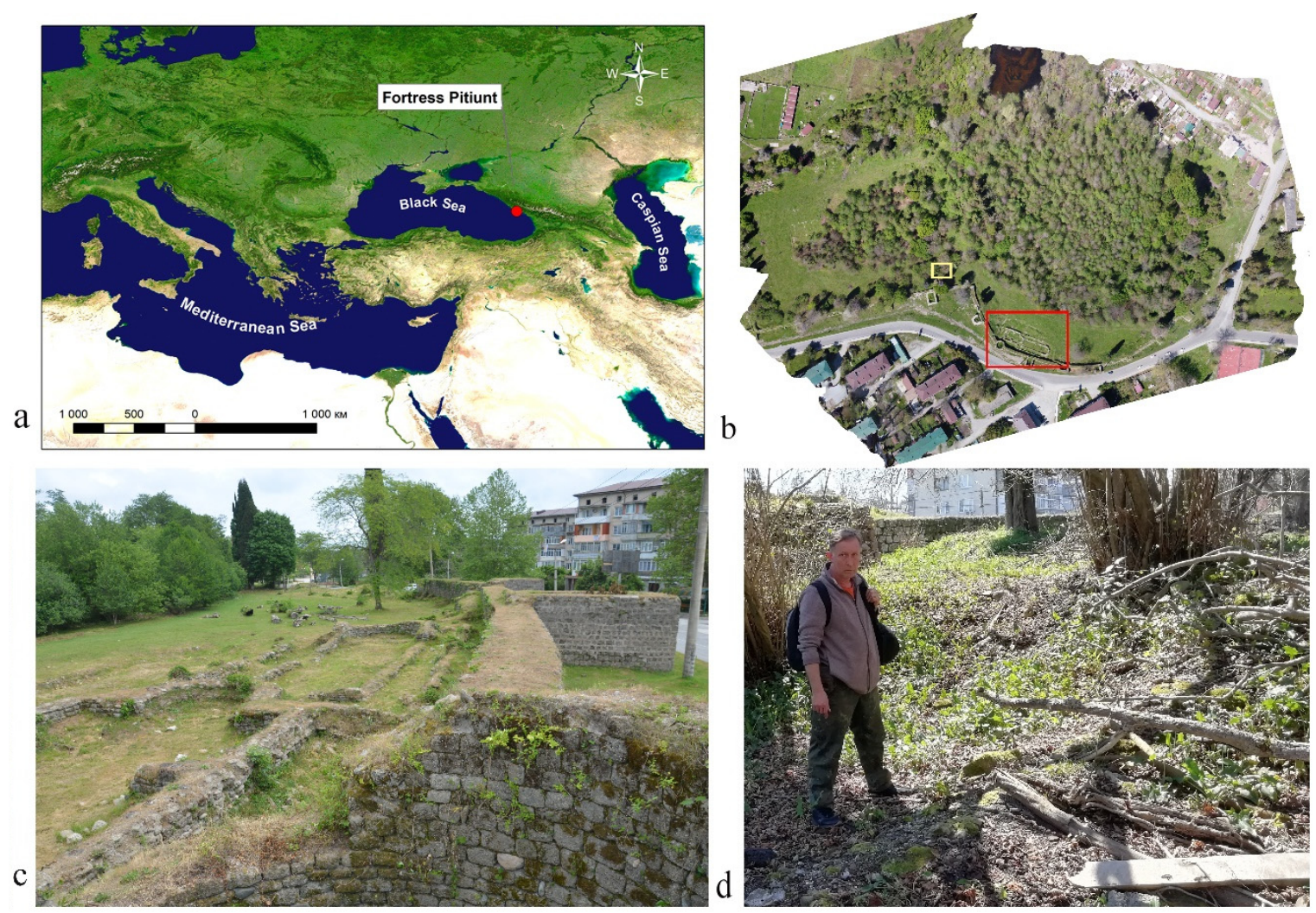

Figure 1. The Roman fortress Pitiunt: (a) localization of the site; (b) view of the site from a drone (a red rectangle marks the view $c$ of the ruins of the temples; the yellow rectangle marks the view $d$ of the wall we have exposed); (c) view of the ruins of the temples from the west; (d) Dr. A. Kizilov stands on a fragment of a stone wall discovered by our expedition, which was not previously marked on the existing plans of the castle. 
For the purpose of achieving the aim, it is essential to draw a holistic picture of what the ancient city of Pitiunt was like and its position in the political and economic life of the Eastern Black Sea region in the first centuries AD and the reasoning behind locating a Roman fortress in the area.

The earliest mention of the ancient city Pitiunt was found in the works of Artemidorus of Ephesus, a famous geographer of the 2nd-1st century BC, quoted by Strabo in his "Geography" (XI, II, 14). Even in those times, Pitiunt was referred to as the "Great", thus proving the existence of a large city. It is obvious that the city was under the influence of the Pontic Kingdom, whose power was gaining strength at that time. At the same time, it remains unclear whether it was a Greek city since "Pitiunt, unlike Dioscurias or Guenos, was not mentioned in any historical source as a Greek colony or a Greek city; besides, there is no archaeological material from the era of Greek colonization and even in the so-called early antique period" [22]. However, this may also mean that the location of the city is still not defined and is awaiting the right moment. Nevertheless, the ancient Pitiunt from the time of Strabo was an important trade center of the Eastern Black Sea region thus been called "Great" (Strabo XI, II, 14).

The political influence of Rome intensified in the 60s of the 1st century, when Nero proclaimed the Black Sea regions as provinces of Rome and brought occupation troops there, as stated in "The Jewish War" (II, 16, 4) written by Josephus. It is possible that Pitiunt suffered a similar fate.

In this context, it is important to note that Gaius Pliny Secundus the Elder wrote in his "Historia naturalis" that the Geniochs plundered "the richest city Pithius" (V.16). The epithet "the richest" indicates that Pitiunt was an important economic center at the turn of the era and played an essential role in the trade in the Eastern Black Sea region, attracting barbarians. It is clear that once in the areas of interest of Rome, this important strategic fortification required protection and control of financial flows, demanding constant troop presence. Therefore, it can be assumed that the first Roman fortress of Pitiunt was built in the second half of the 1st century AD after the invasion of the Geniochs. It is possible that before the II century AD it had been made of wood, which explains the absence of finds dating back to that time on the site of Pitiunt.

In 134 AD, Pitiunt was mentioned in the work Periplus written by Flavius Arrian, where he wrote "if we move from Dioscurias, the first stop will be in Pitiunt, at a distance of three hundred and fifty stades" (Arr., 27), implying the presence of a harbor or a dock for ships. The location of the harbor will be discussed below. As for the investigated fortress Pitiunt, its construction should be attributed to the times after the writing of "Periplus" by Arrian, i.e., not earlier than the second half of the 2nd century AD.

Zosimus, a Byzantine historian of the late 5th-early 6th centuries, in his "New History" described the raids of the "Scythians" (Goths) on Pitiunt in 256-257 AD, mentioning an important detail "Pitiunt was surrounded by a huge wall and had a very convenient harbor" (I, 32-33), which suggests that by the middle of the III century AD, the western part of the fortress had already existed and had been a significant fortification. The building of a Roman fortress in the "Great Pitiunt "was not meant to influence the local rulers but meant as the protection of a large trading center from the barbarians from the north.

Historical records representing the role of Pitiunt in the structure of the influence of Rome on the Eastern Black Sea region in subsequent years include the "Church History" of Theodoret, Bishop of Cyrus. While describing the resettlement of John Chrysostom (V century AD), he mentions the location of Pitiunt that "this is the farthest extent of Pontus and Roman power" (V, 34), which means the Pitiunt was a border fortress of the Roman Empire in the diocese of Pontus.

References to the "Great Pitiunt" and its fortress found in the works of ancient authors are very scarce. However, they offer an insight into the essential mission that the Pitiunt fortress carried in advancing the interests of the Roman Empire in the Eastern Black Sea region. 


\section{Materials and Methods}

In order to accomplish a historical architectural reconstruction, it is essential to study the historical, geological, archaeological and architectural aspects associated with the investigated site $[9,23]$, equally to conducting our own surveys and explorations at the site. This implies:

1. Analysis of available historical evidence about the city and fortress Pitiunt in order to understand its economic, political and military role in the Eastern Black Sea region and determine the chronology of the fortress development in the first centuries AD;

2. Study of materials on the geology of the area for paleoreconstruction of the coastline and landscape of the Pitsunda Cape in the first centuries AD facilitates a deeper understanding of the fortification significance in the period under study and its decline in the subsequent period. This aspect is of crucial importance, since often the modern landscape differs considerably from what it was during the time when the fortress was used. Mainly, the changes in the landscape led to the fact that the fortifications or settlement ceased to function and were abandoned;

3. The use of materials from archaeological research, which are the major source of data about the architecture of the Pitiunt fortress. The combination of archaeological records and analysis of historical evidence would allow to clarify the chronology of the stages of construction of the site;

4. Analysis of the architecture of similar fortifications, civil and religious buildings of the period under study [10-18]. Due to the high degree of architectural standardization in the Roman Empire, especially in construction of fortifications, such analysis enables restoration of the missing archaeological data for the Pitiunt fortress, since firstly, the territory of the fortress had not been explored up to the "mainland" in order not to damage the richest material 3-4 AD discovered during the excavations, and secondly, excavations of only $15 \%$ of the territory of the western fortification were done, and therefore, for a full reconstruction of the entire territory of the fortress, it is necessary to turn to research materials from other fortresses of the Empire of the same period;

5. By carrying out our own examinations and reconnaissance on the territory of the fortress, it is possible to check the available archaeological data, correspondingly identifying previously unrecorded sections of walls and structures that are found above the ground due to the continuous process of erosion and weathering.

Let us consider in more detail the aforesaid aspects. Issues related to historical sources, which mention the city and fortress of Pitiunt, were discussed in detail in the introduction. As regards the paleoreconstruction of the outlines of the Pitsunda Cape in the 3-4th century $\mathrm{AD}$, the geological studies of the Black Sea coast of the Caucasus, was carried out in the 80s of the 20th century [21], which permitted to model the outlines of the coastline in the fortress area.

According to geological studies, in the central part of the peninsula during the Nymphaeum transgression, a brackish lagoon with a strongly indented coastline was formed, occupying a significant part of the Pitsunda Cape, which was fed both from one of the branches of the river Bzyb and networks of smaller rivers of the Musser Upland. It had a channel to the sea in the western part of the cape, plus "in the eastern part of the peninsula in the area of the lake Pitsunda was connected to the water area of the Pitsunda Bay, and was used by the ancient Romans as an internal harbor" [21] (Figure 2). 


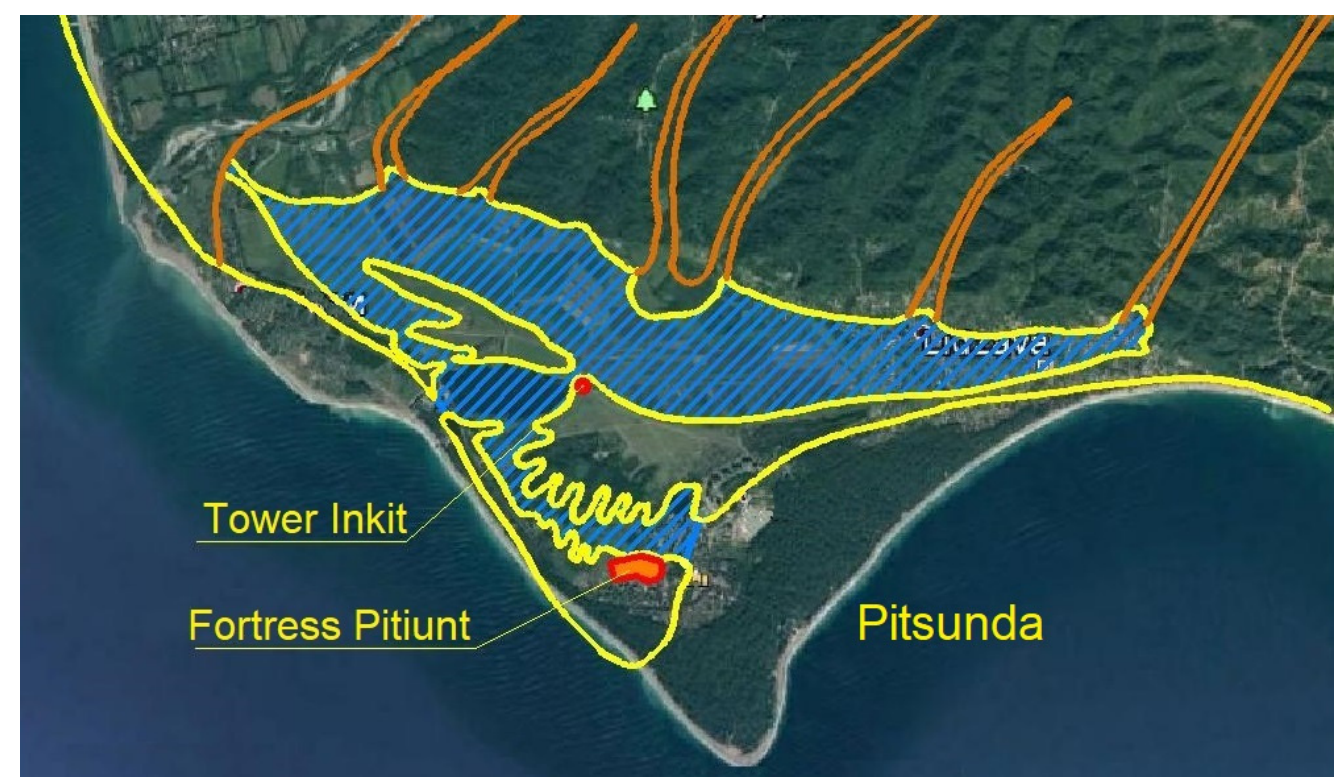

Figure 2. The outlines of the coastline of the Pitsunda Cape in the first century AD.

Therefore, in the first century AD, the territory of the fortress was located on an island in the delta of the river Bzyb, similar to the fortification of Phasis in the delta of the Rioni river [23]. During the prosperity period of Pitiunt, the inner lagoon was located very close to the fortress, which provided, on the one hand, protection from attacks on the fortress from the land, and on the other hand, the convenience of docking, loading and unloading the ships, etc. As illustrated in Figure 2, the fortress was built on the southern side of the cape, formed by a channel into the inner waterways of the Pitiunt harbor and the Pitsunda Bay. The fortress guarded the entrance to the harbor, the complex system of which included the modern lake Inkit. Between the lake and the large inner harbor adjacent to the Mussera Upland, there was a narrow strait, controlled by the Inkit Tower in the south. The Pitiunt fortress with the Inkit tower constituted one fortification complex guarding the access to the inner bay, on the banks of which, perhaps, traces of the ancient city of Pitiunt should be searched for. The described picture makes us reassess these long-known monuments that do not fit into the modern relief. In this scenario, the meaning of the presence of "scorpions", the parts of which were found during archaeological excavations on the fortress towers, becomes clear [24,25]. Apparently, the purpose of these catapults was aimed, among other targets, at fighting ships, not only defending the curtain walls from the barbarian infantry.

Geological evidence indicates that the entrance to the harbor from the Pitsunda Bay could have existed until the 6th century AD, the time of the late period of the history of the fortress, although "the connection with the waterways of the Pitsunda Bay could be preserved only on condition of artificial support of the original natural passage" [23]. At a later time, the attenuation of the Nymphaeam transgression process led to the drainage of this territory, the alluvial coastline in the eastern part of the cape, the desalination of the lagoon and its swamping. Presumably, these factors, along with an outbreak of malaria, were some of the reasons the fortification was abandoned in the 6th century.

Now let us address the available archaeological materials of the fortress. The findings from archaeological excavations done by the Pitsunda archaeological expedition on the territory of the fortress from 1952 to 1974 were used while developing the model. At the beginning of the investigation, the fortress consisted of the ruins of walls and towers made of blocks of a marine conglomerate, about a meter high, which are now separated by a concrete belt from the walls that were erected during the restoration work of the 70s of the twentieth century. The total area of the fortification is about 6.5 hectares, the length of the outer walls is $1200 \mathrm{~m}$, the total number of identified outer towers is 27 (only 4 have been excavated). During the twenty-two years of the expedition, twenty-one excavations 
were laid with a total area of about one hectare. Although this makes up about fifteen per cent of the entire inner area of the fortress, the study made possible to reveal the outlines of residential and administrative buildings, garrison and thermal baths attached to the eastern side of the first castellum, together with a multi-layered church complex on the territory of the eastern fortification called canaba.

The result of this work was obtaining the general plan of the fortification, published for the first time in 1975 [26], which formed the basis for our 3D reconstruction of the fortress. A joint analysis of the general plan and historical information about the city and the fortress of Pitiunt allowed us to gain essential data about the chronology of the monument and the stages of its development. The general plan shows that the fortified part of the Great Pitiunt consists of three main parts (Figure 3).

1. The western part which is the castellum is the earliest classic Roman castellum $155 \times 130 \mathrm{~m}$ with a central street along the East-West axis, starting at the eastern gate formed by a protruding double tower, and ending at the praetorium in the western part of the castellum. Narrow lanes derive from the main street in both directions with symmetrically located structures for various purposes built in accordance with strict regulation and rules of the Roman fortification architecture, related to castellum (Figure 3a).

2. The central part is the space between the eastern wall of the castellum and another wall parallel to it, at a distance of $75 \mathrm{~m}$ to the east. This area is a later expansion of the castellum to the east, which, apparently, had not been completed (Figure 3b).

3. The eastern part canaba is semicircular; it was built later, and it varies from the western part not only in the shape but also in the thickness of the walls, the length of the curtain walls, i.e., in the eastern part, the walls are thinner, and the curtain walls are shorter (Figure $3 c$ ).

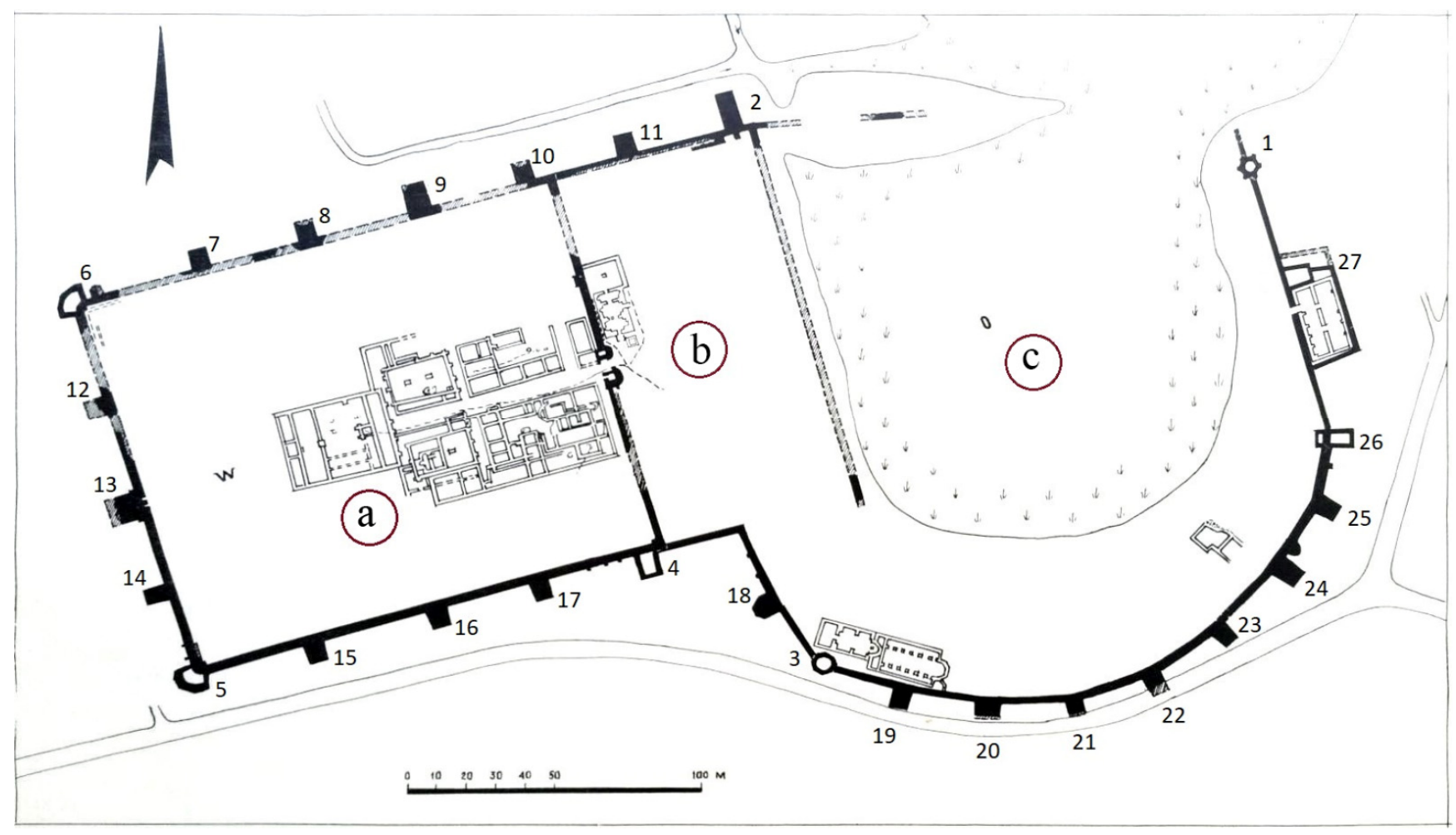

Figure 3. General plan of Pitiunta fortress, adapted from ref. [26]: a—castellum (end of II-beginning of III centuries AD); $\mathrm{b}$ - expansion of the castellum to the east (middle of the 3rd century AD); c-canaba (late III-mid IV centuries AD).

In addition to excavation plans, we examined the entire accessible territory of the site, which made it possible to clarify and supplement the available material. Therefore, in 
particular, a fragment of a stone wall about eight meters long not marked on the existing plans of the castellum was revealed (Figure 1d). It is located outside the east wall of the castellum, midway between tower 4 and the eastern gate. Having a thickness of about eighty centimeters in the above-ground part, the wall stretches at a right angle towards the canaba. It is probable that during the archaeological excavations carried out by the Pitsunda archaeological expedition on the territory of the fortress from 1952 to 1974, this area could have been located deep in the thickets under a layer of humus and was not visible. Obviously, after clearing the territory of the fortress from thickets for further use by the tourist industry, the bush was cut down, and the humus was washed away by the abundant precipitation for the region, exposing the contours of the wall. We believe that future archaeological excavations and analysis of the composition of the limestone solution of the wall will assist to date this site, as was earlier the case with dating the Kelasur wall, an important historical site of the region [27]. At the moment, we can only assume that it had been either an unfinished part of the second stage of construction of the fortress, or the remains of the tower of the first castellum, a symmetrical tower number 14, which was later dismantled for materials for the construction of a canab.

All these parts comprise a single fortification, but they are of different times.

Based on the excavations results, the chronology of the monument is the following:

- At the end of the 2nd-beginning of the 3rd century a classic Roman castellum of rectangular shape was built (Figure 3a);

- In the middle of 3rd century, the castellum was expanded to the east (Figure 3b), which most likely coincided with a series of barbarian invasions in the second half of the 50s of the 3rd centuries when the fortress was captured, destroyed and burned, and the garrison were killed;

- At the end of 3rd-4th centuries $\mathrm{AD}$, the fortress was restored, and the eastern part of the fortification (canaba) was constructed (Figure 3c); it was the prosperity period of the fortress, and the first Christian churches were built in the territory of northwestern Colchis;

- The 5th century AD was the period of the city's decline;

- The first half of the 6th century was the era of Justinian and the second flourishing of Pitiunt;

- In the middle of the 6th century, the fortress was abandoned by the garrison before the invasion of Mermeroy, and the life in the city faded;

- The second half of the 6th century was the flourishing of the fortress as a Christian center of early medieval Abazgia.

3D reconstruction of the appearance of the Roman fortress Pitiunt as of the 4th century $\mathrm{AD}$ was carried out based on the abovementioned chronology and the plans for the fortification obtained in the course of excavations. This time period was targeted specifically since it is the heyday of Pitiunt which is proved by overwhelming number of findings on the site of the fortress. By that time, the construction of the entire complex of fortifications had been completed and the first Christian churches had been built in the territory of northwestern Colchis.

As mentioned above, the excavations revealed mainly the central part of the western fortification, which is not sufficient to fully visualize of the object; therefore, this reconstruction is impossible without an analysis of the architecture and planning of Roman fortifications of the 3-4 centuries AD. This is facilitated by abundant research into this aspect and the large quantity of material on 3D reconstruction of similar sites [10-18]. Since the fortification on the territory of the Roman Empire was largely standardized, in our case, the choice of method of reconstruction by analogy can be quite justified, at least for the territory of the castellum, especially since we do not pursue the aim of creating a detailed reconstruction of the object due to insufficient preservation and archaeological study of the site, and we strive to convey the general view of the fortress, inscribed in the ancient landscape. 
Moreover, in some places, i.e., in the northern part of the canaba (Figure 3c), due to the lack of archaeological data, when reconstructing a section of the wall, it was required to proceed from the general principles of fortification while maintaining the distances between the towers, which corresponds to the general architecture of the fortress. In those areas where there was no archaeological material available, we created the model based on analogies with other fortifications, using the principles and rules of fortification and general architectural and construction considerations.

Abovementioned are the main aspects and principles that were used in the present work. At each stage, we were guided by the "principle of transparency" defined by the London Charter [21] and more specifically, in the field of archeology, the Seville Principle [28]. However, we did not use the color scale to display historical and archaeological evidence, as suggested by a number of experts [29]. In our opinion, such a multi-colored model will lose its visibility and will be incomprehensible to most users

Let us consider the methods used in the reconstruction.

The fortress model was created in Autodesk 3ds Max using polygonal modelling. As a basis for modeling, a plane was taken with a superimposed scaled general plan of Pitiunt Fortress, obtained from the results of excavations in 1952-1974. Each element of the fortress (section of the wall, tower) was outlined along the contour on the plan, adjusted according to the descriptions of the Pitsunda expedition [30] and stretched at the required height (Figure 4). The height of the walls was determined by the length of the base of the stone stairs running along the fortress walls in the area of towers No. 2 and 5, identified by the Pitsunda expedition. Their length is 7.5-8 m. with a tread depth of $30 \mathrm{~cm}$; the total number of steps totals about 25 , which with a step height of $20 \mathrm{~cm}$ determines the height of the wall of about $5 \mathrm{~m}$ and is consistent with the height of the walls of the perfectly preserved Roman fortress Apsar, built at the same time as Pitiunt and which had a similar purpose, size and number of towers [30]. The height of the parapet was taken as standard for fortifications of that time as $2 \mathrm{~m}$ and the height of the embrasure base at $1 \mathrm{~m}$. The widths of the merlons and embrasures were taken as typical for late Roman fortresses of 2 and $1 \mathrm{~m}$, respectively [8]. Having studied the nature of the stone stairs leading to the walls in the area of towers No. 2 and 5 , we found that by the first staircase it was possible only to get to the wall between towers 2 and 11, and the passage towards the canaba was blocked by two wide breaks in the base of the stairs at $3,5 \mathrm{~m}$, over which the drawbridges were probably lowered. The second staircase led to the center of the fan-shaped tower No. 5, probably indicating that access to the walls was limited by doors in the upper level of tower No. 5. Based on this, we concluded that the towers of the fortress had to rise above the walls by one level and prevent free passages between curtains, which we kept in the model. The height of the upper platform of the tower was made $7.5 \mathrm{~m}$ in order to ensure a minimum required height in the interior, taking into account the beams and the ceiling.

The texture of the masonry the blocks of the sea conglomerate was implied on the fortress walls and towers, photographs of which were made by our team during exploration of the existing sections of the fortress wall. The structure of the towers in the model was made with Opus Mixtum masonry, which does not contradict the results of our investigation of the site. A belt of similar masonry was found in the surviving fragments of the walls of Tower No. 5.

After building the geometry of the fortress, a landscape was created on the basis of a paleoreconstruction of the terrain made according to [21]. In order to do so, a scaled map was imposed on a $1 \times 1 \mathrm{~km}$ plane of the southern tip of the Pitsunda Cape, during the period of the 3rd-4th centuries $\mathrm{AD}$ was produced, partially including both the seaside coastline and the internal outlines of the Pitsunda harbor, where the fortress was located.

We placed two planes above it, creating the water surface and the terrain. The terrain plane was converted to a polygonal surface and deformed by extrusion according to the coastline map. In the area of the fortress, the polygonal mesh was made finer to ensure greater accuracy. The terrain was combined with the fortress and adjusted in place; a moat was modeled around the fortress, getting the water from the Pitsunda harbor. 


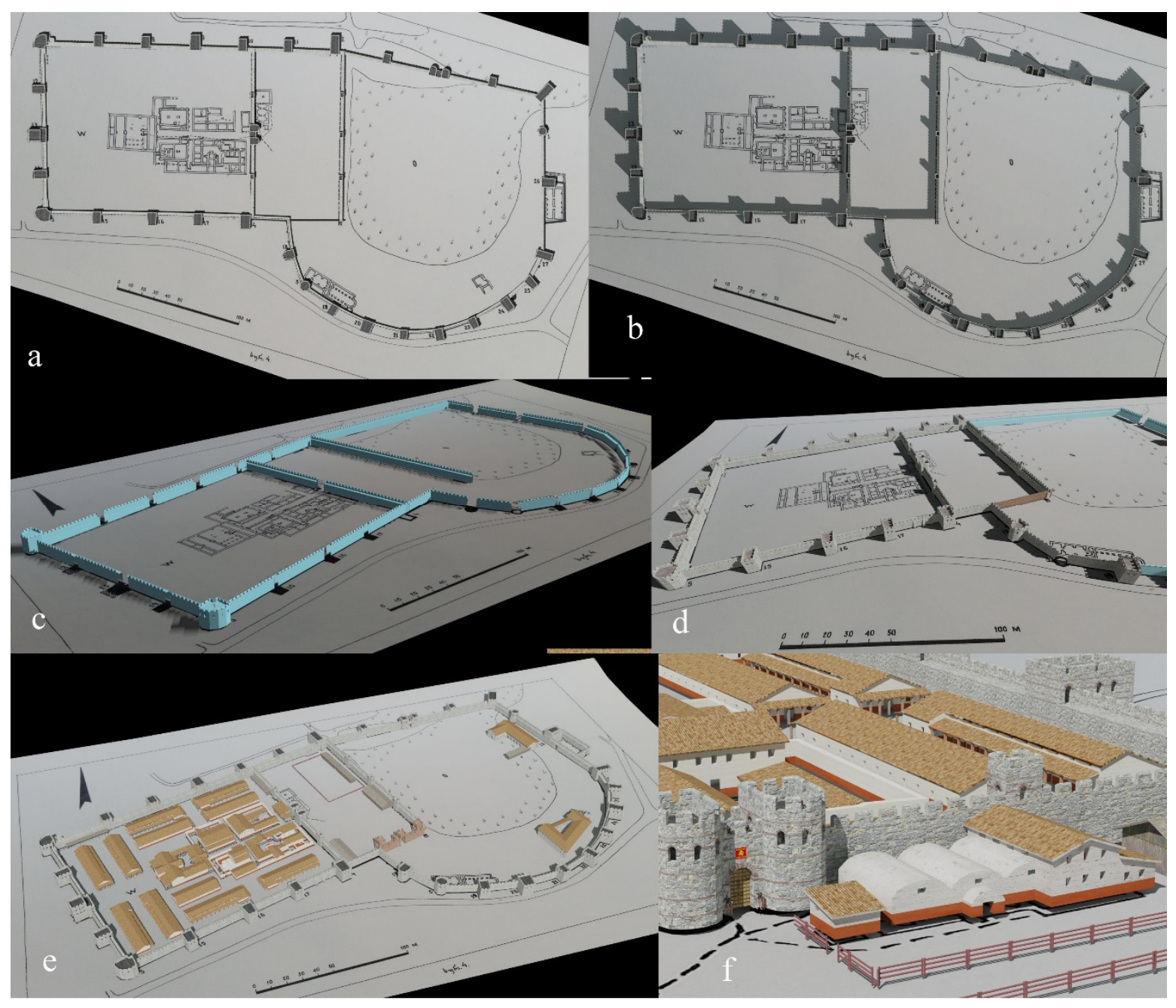

Figure 4. Stages of modeling: (a) creating the outlines of walls and towers; (b) raising the contours of the walls to a certain height; (c,d) texture mapping; (e) creation of internal planning; (f) reconstruction of small artistic details.

Trees and shrubs have been added to the scene in combination with different textures of the underlying surface and haze in order to increase the realistic perception of the model.

These were the methods and considerations applied in the reconstruction of the exterior of the Roman fortress of Pitiunt.

\section{Results}

Archaeological work carried out on the territory of the Pitsunda Cape revealed two fortifications dating back to the late Roman time: the Pitiunt fortress and the Inkit tower, existing in the same period. Considering these objects in the modern landscape, it is difficult to understand their fortification purpose, since the fortress is located in the depths of the cape at the bank of the swamp, and the tower is in the center of the cape on the bank of the boggy lake Inkit. Having been built in such a location, they could not be used for protection of anything. Considering the high fortification art of the Romans, this choice of a place for fortifications seems more than bizarre.

However, the performed paleoreconstruction sets a new focus on this fortification complex, which played an important role in the defense and control of the territory. Fortress Pitiunt protected from the enemy the entrance from the sea to a convenient inner harbor located on the site of present-day Inkit Lake, and the Inkit Tower was probably designed to control a narrow passage to the harbor from a large inland bay (Figure 2). On the shores of this bay, perhaps the ancient city of Pitiunt should be sought. One method of such 
protection could be the pulling of a chain from the Inkit Tower, blocking the exit to the sea from the inner bay, which provided an important tool to influence the local population.

It must be understood that the Pitiunt fortress in the 3-4 centuries was not just another internal fortification in the network of the Black Sea Limes but a border outpost, where the lands of the barbarians began, so its virtual reconstruction is of particular interest.

Excavations of the Pitsunda archaeological expedition have exposed almost the entire perimeter of the fortress walls, with the exception of the northern wall of the canaba, since their current location is a swamp (Figure 3c). Analysis of geological data shows that the harbor of the "Great Pitiunt" approached the fortress in this very place. Prior to the excavations, several scientists had suggested that the eastern part of the semicircular fortification was the inner port of the fortress. However, the study of the site between Towers No.1 and 2, with a length of about $160 \mathrm{~m}$, revealed the presence of fragments of the fortress wall along the entire length immersed in a swamp [31].

Due to the waterlogging, not a single tower was identified. According to Apakidze A.M., there should be fewer than 6-7 of the towers. Proceeding from this and from the fact that there were no main gates on the cleared sections of the walls of the canaba, it was assumed that they could have been in the middle of the northern wall entering the harbor. By analogy with the eastern gates of the castellum (Figure 5) and other Roman fortresses of the 3rd-4th centuries, they could have represented a double D-shaped tower, with an arch of the gate in between (Figure 6).

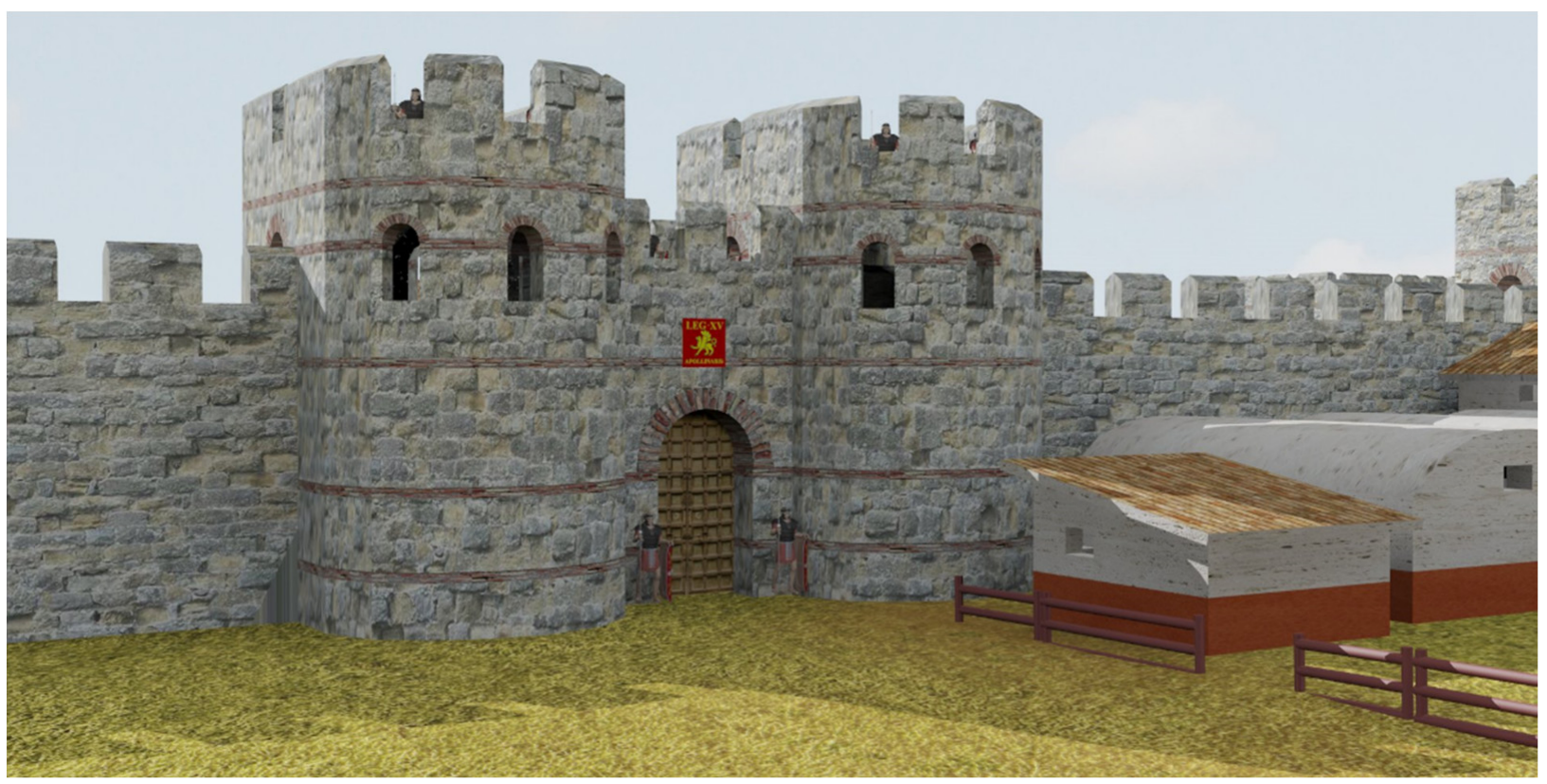

Figure 5. East gate of castellum.

On the northeastern corner of the wall, according to the general principles of Roman fortification, we placed the corner tower, and the remaining space of the northern wall of the canaba was filled with middle towers based on the average length of the curtain walls of the eastern part of the fortification. There were four missing towers in total, which does not oppose the theory of Apakidze A.M. The walls of the fortress, by analogy with other Roman fortifications of that time, were probably surrounded by a defensive moat along the perimeter, which had breaks only in the gate, which was shown in the model.

According to the results of the excavations of Tower No. 1, the construction of the canaba wall belongs to the period of our reconstruction since an early layer with redlacquered utensils typical of the 3rd-4th centuries was found [31]. 


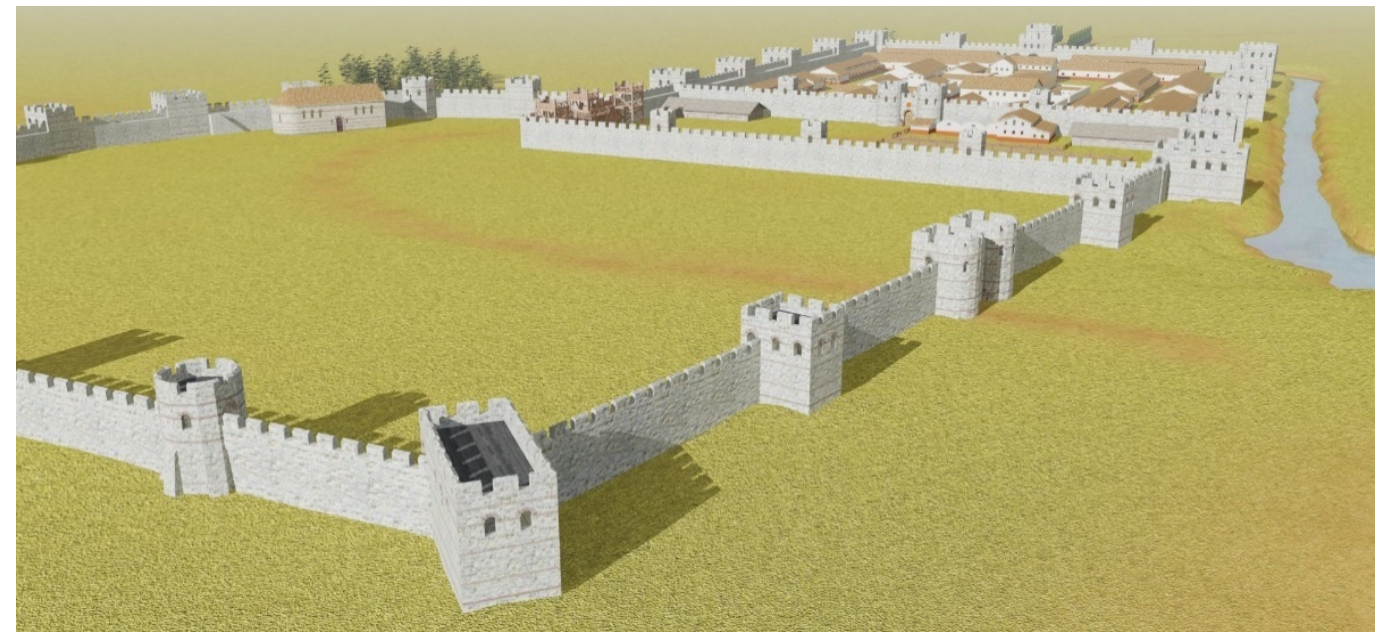

Figure 6. Reconstruction of the northern wall of area 3 (canabas).

In relation to the shape of the castellum itself, it can be assumed that it had survived at least two periods of construction: in the beginning (late second-early third centuries AD), it was a rectangular classic Roman castellum measuring $130 \times 155$ m, formed by four corner towers and twelve middle towers. The east corner towers appear to have been rebuilt in the second construction period at the time when the castellum was expanded to the east. This is evidenced by the wall, uncovered by the excavations, which runs from Tower No. 2 to the south, parallel to the eastern wall of the castellum. It was erected to the east by $75 \mathrm{~m}$, increasing the size of the fortress to $130 \times 230 \mathrm{~m}$. According to A.M. Apakidze, the expansion of the castellum took place in the second half of the 3rd century [30]. If we correlate this with the events of the second half of the 50s of the 3rd century AD, described by Zosimus, it can be assumed that the restructuring of the fortress could have begun after the Goths were repelled by Sukessian in 256, but the restructuring had not been completed until the fall of the fortress in the second wave of the invasion. The towers of the northern wall indirectly prove the rebuilding of the castellum. The general plan shows that Tower No. 2 was planned to be the corner tower, and tower No. 9 was for the central one, since it is larger than towers No. 7, 8, 10 and 11. Tower No. 4 was preserved in the southern section of the corner, and Tower No. 16 in the central one. The number of towers on the northern and southern walls of castellum, along with the asymmetry of towers 9 and 16 relating to the main axis of the fortification, indicate that the northern wall was rebuilt; the building of the eastern wall was started; however, there was insufficient time to start rebuilding the southern wall of the castellum.

It is possible that at the end of the 3rd century, during the restoration and reconstruction of the fortress, the was no necessity to complete the eastern part of the castellum due to the construction of the canaba. Simultaneously, the remaining eastern wall was used to separate the territory from the canaba. Garrison baths were revealed during excavations, together with warehouses, cattle pens, workshops, etc. (Figure 7). 


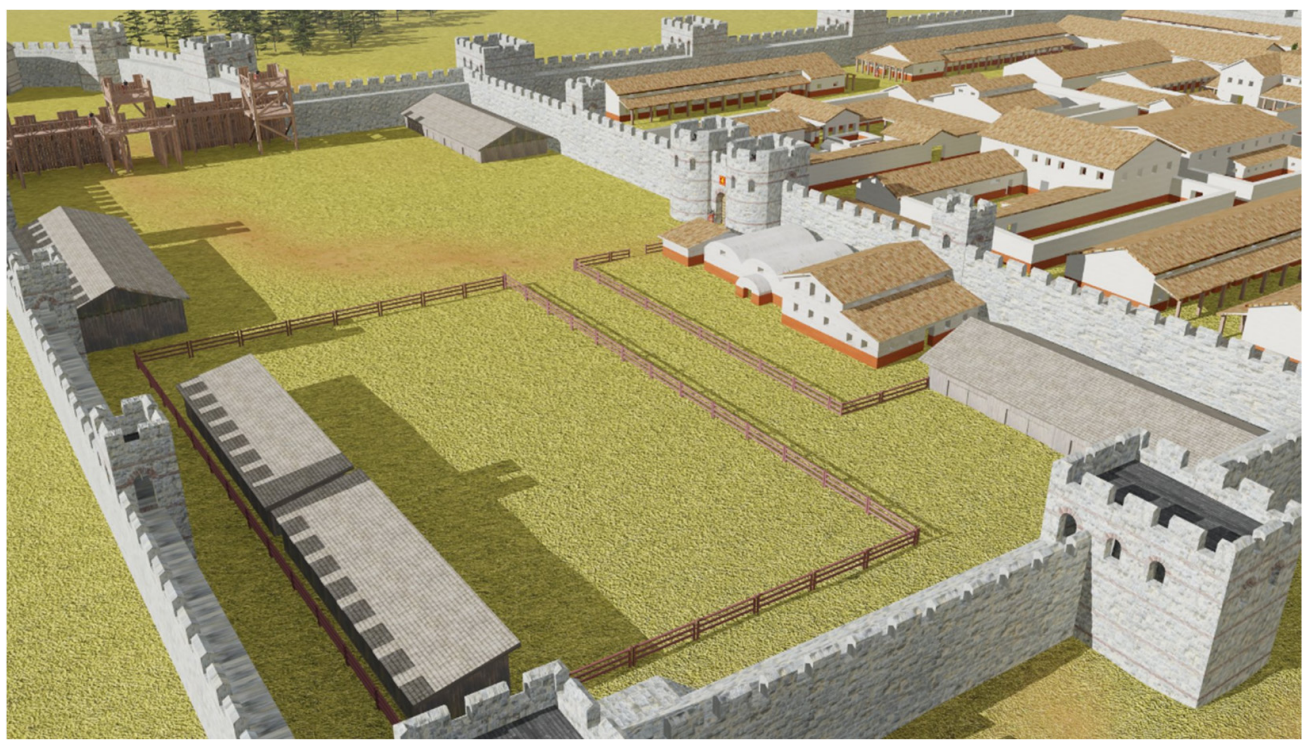

Figure 7. Reconstruction of the central part of the fortress (area 2).

It also served as a buffer zone between the canaba and the first castellum-citadel in the event of enemy seizing the eastern part of the fortress. Since the excavations did not reveal a section of the wall enclosing area 2 from the south, it can be assumed that this section was made with a wooden palisade with towers and gates, which is often found in the structures of Roman fortifications (Figure 8).

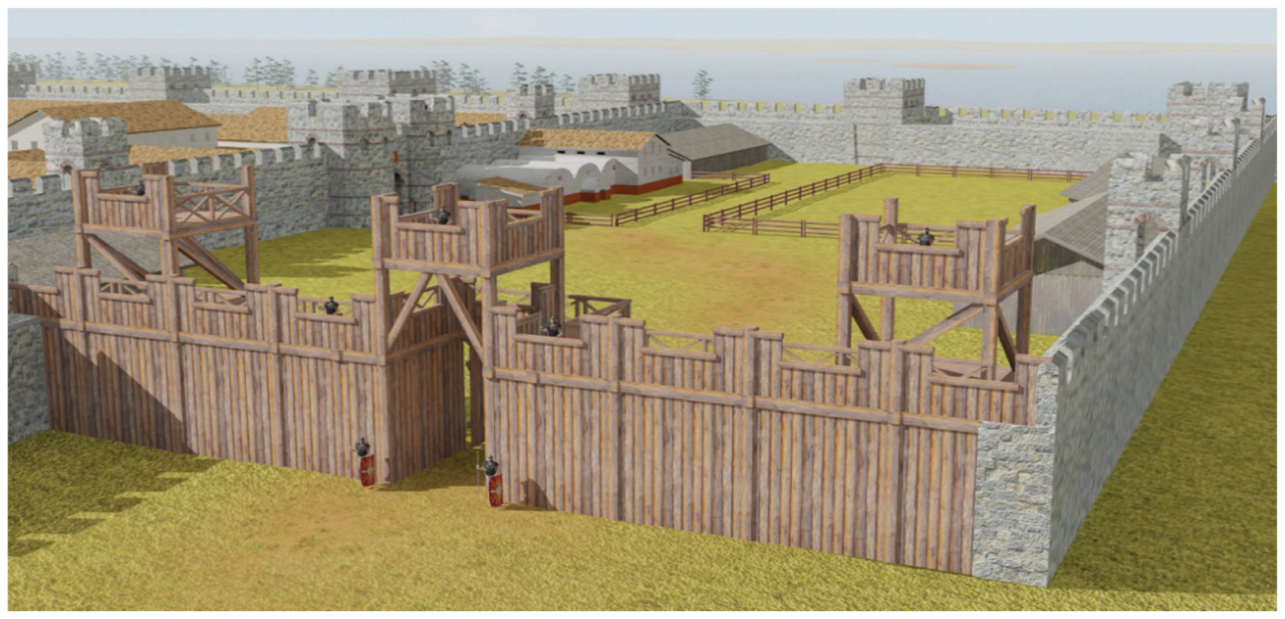

Figure 8. Reconstruction of area 2 behind the eastern wall of the castellum with garrison baths, and buildings for various purposes.

The reconstruction of the western wall of the castellum is of special interest. It is formed by five towers (No. 5, 14, 13, 12 and 6). The fan-shaped form of towers No. 5 and 6 is typical to the era of Emperor Constantine and later, and therefore, perhaps, we can find a later reconstruction of the fortress. Inspection of these towers revealed that they were attached to the rounded corners of the fortress wall, distinctive of earlier Roman fortifications. Tower No. 13, located in the center of the western wall, is larger than the others, "therefore, it can be assumed that it defended the large western gate... the 13th tower, in terms of its location and strength of structure, must have been the main entrance-the portico of castellum" [32] (Figure 9). 


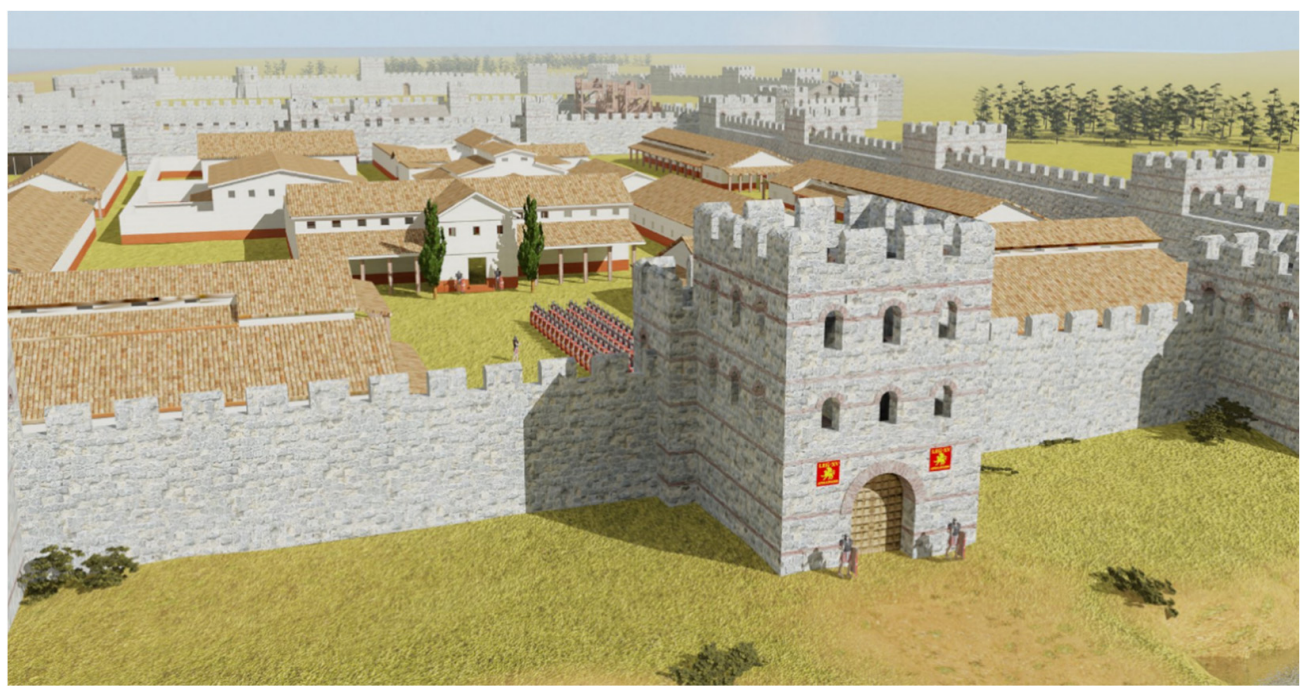

Figure 9. Reconstruction of the western gate of the fortress.

The reconstruction of the inner part of the castellum was carried out based on the research of the Pitsunda archaeological expedition done in excavations V, VI, IX, XIII, XVI, XVII, XVIII, XIX, together with analogies with the already studied and reconstructed Roman fortifications of the III-IV centuries AD. The fact that the structure of Roman fortifications at that time was standard and followed the same planning rules facilitated the task.

In the central place of the castellum, there is praetorium building located in the western part of the fortification at the end of the central street, which stretches from the eastern gate along the E-W axis (Figures 10-12). On both sides of the street, there are residential and administrative buildings, three of which have at least thermal baths.

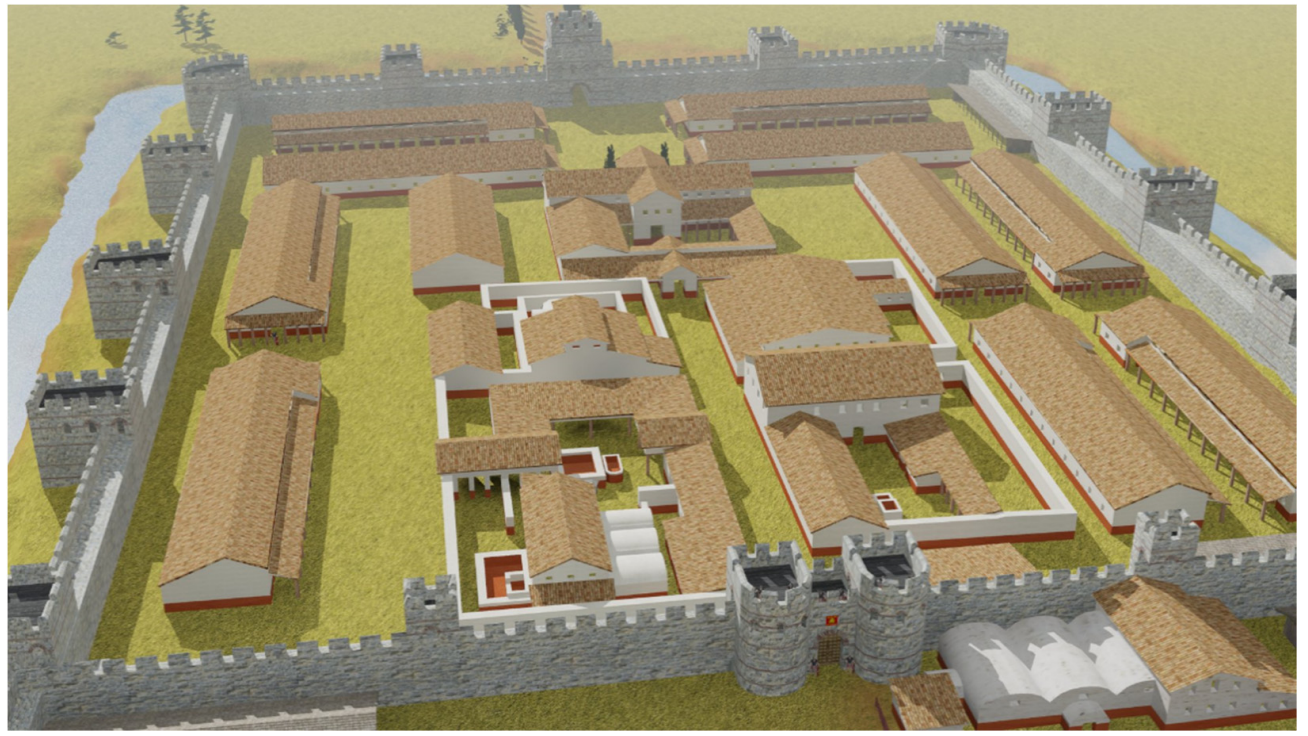

Figure 10. General view of the castellum from the eastern gate. 


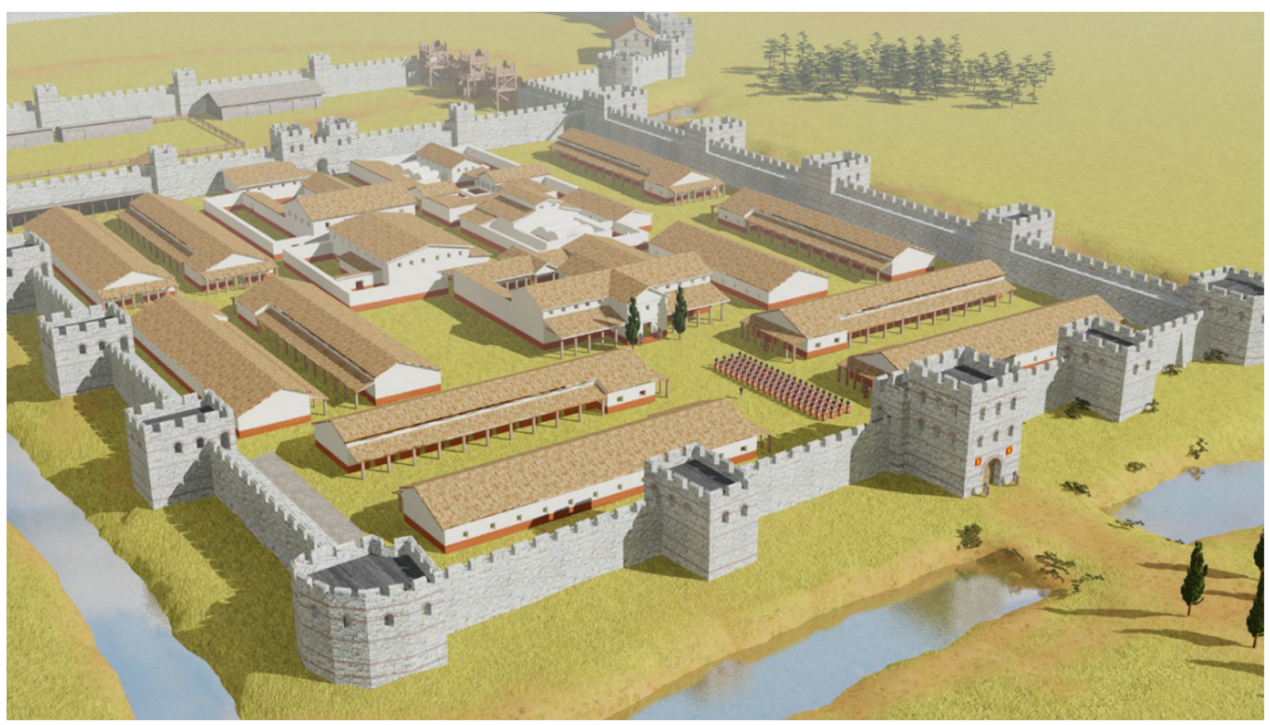

Figure 11. General view of castellum from the northwest.

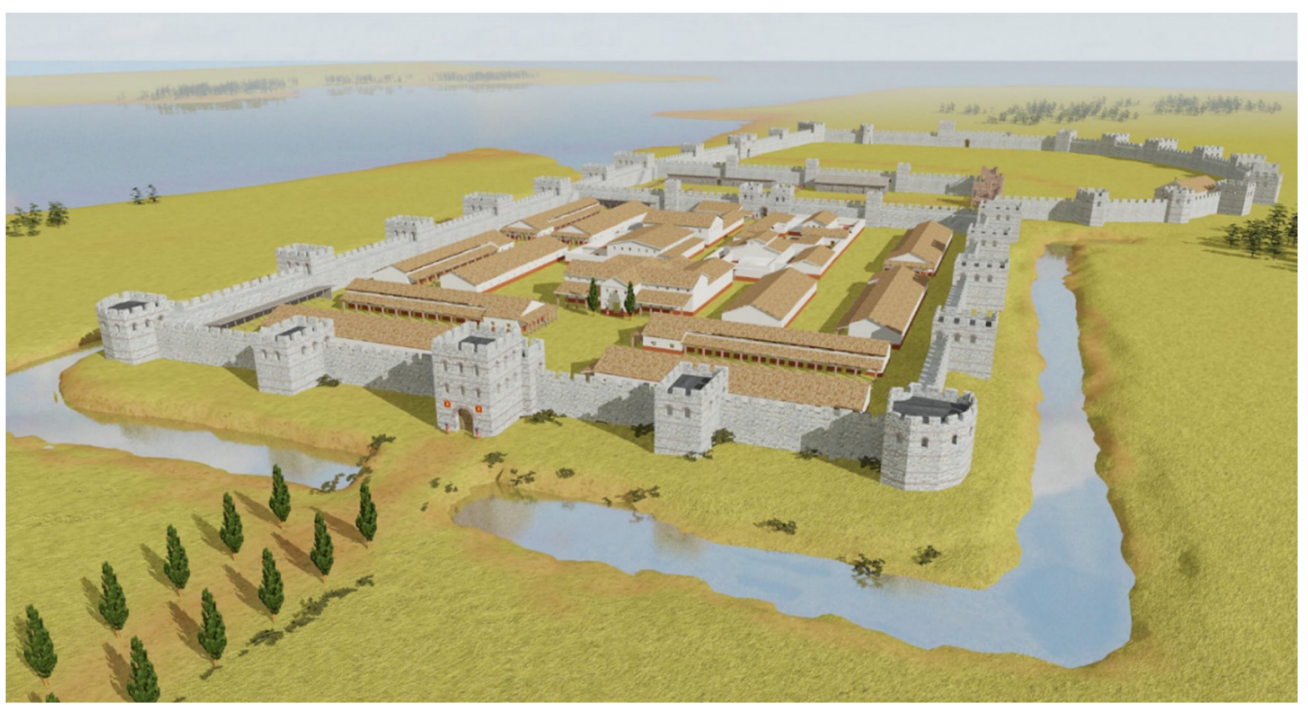

Figure 12. Reconstruction of the general view of the fortress "Great Pitiunt".

Armories, warehouses, a hospital, stables, etc. needed to be placed inside the fortress. In the proposed model, the opinion of A. M. Apakidze that all relatively important structures of the "Great Pitiunt" were covered with tiles at one time was taken into consideration. The lower part of all buildings in the 3D model was "plastered" with cementum (lime-based plasters with fine ground brick content), since this technique was used by the Romans everywhere to protect against moisture, and A.M. Apakidze noted the appearance of the lime-based plasters with fine ground brick content-cementum in vast amount.

The space around the praetorium along the northern, western and southern walls of the castellum was not excavated by the expedition, but by analogy with other Roman fortresses of that time, barracks could have been located here. When modeling this site, barracks were built according to the Roman standard, including 20 rooms for 4 people with two bunk beds and a room for a centurion (since the number of centuria in the 3 rd-4th centuries was 80 people). The designated space accommodates up to 10 barracks, which makes it possible to estimate the size of the military garrison at 500-800 people, which corresponds to one Roman cohort. As is known, the vexillation of the XV legion "Apollinaris" was quartered in Pitiunt, the symbols of the legion were found on bricks and clay slabs during excavations of the fortress and the area [33]. 
The territory of the canaba was not excavated by Pitsunda archaeological expedition, with the exception of excavations III and XX; therefore, it was not reconstructed in the model, in order not to be too speculative. Nevertheless, it is clear that residential quarters, retail space, warehouses, inns and other infrastructure elements of such an important trade and economic center of the Eastern Black Sea region as Pitiunt were located here.

Of particular importance is the visualization of the appearance of the Pitiunt churches located in the territory of the canaba (Figure 1), since they are the first churches built in northwestern Colchis.

Church No. 1 is the oldest. It is a one-nave hall building with a semicircular apse $[34,35]$. It is believed to have been erected before 313-332. and was the cathedral of the Bishop of Pitiunt Stratophilus, a participant in the First Council of Nicaea in 325. At the same time, Christianity in Pitiunt had become widespread much earlier than 325, when Pitiunt had formed a church organization headed by the city bishop. Church No. 1 has rather thin walls, which in combination with a single-nave structure and a significant width of $11.3 \mathrm{~m}$ excludes the presence of a stone vault and suggests that the roof of this structure was made of rafter (Figure 13). The synchronicity of the temple with the canaba wall is currently debatable, but the dating of the early layers in Tower No. 1 to the end of the 3rd-beginning of the 4 th centuries is acceptable. The church did not last long and was destroyed by fire. In its place, Church No. 2 was built in the middle of the 4 th century. Its reconstruction was not done, since for the non-standard asymmetric apse the analogies have not been found yet and this issue requires further study. This church did not last long either, and Church No. 3 was built in its place.

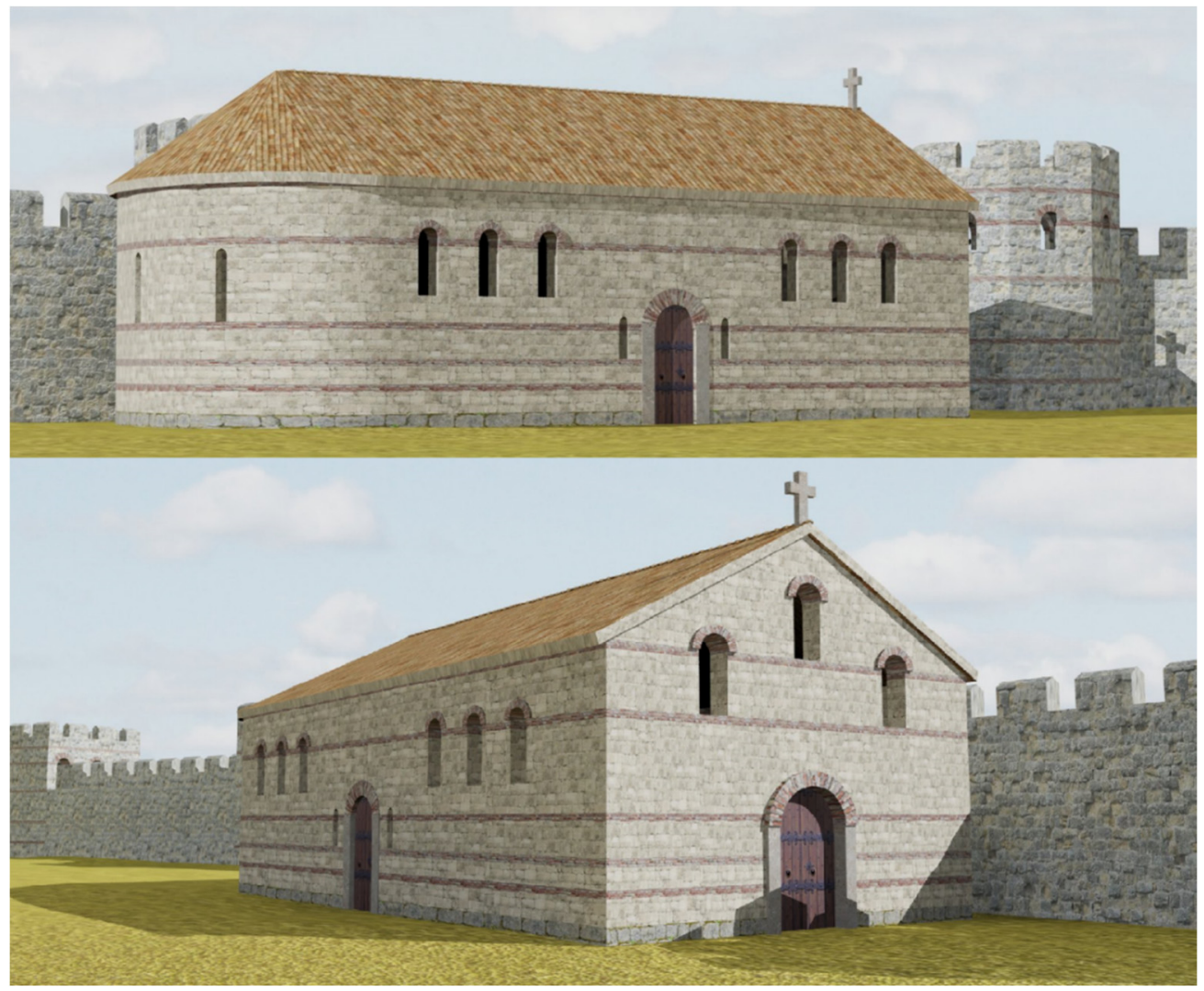

Figure 13. Reconstruction of the appearance of the Church No. 1.

Church No. 3 survived better than the previous monuments in the Pitsunda complex and is larger than the two earlier ones (Figure 14). Unlike them, this church can already be considered an exemplary basilica building of the Roman-Byzantine style. The division of the inner part of the building, the presence of a faceted apse on the outside, axial and 
longitudinal entrances, as well as three entrances from the narthex, a semicircular altar part and alternation of stone rows with brick in the building material testify the influence of the Hellenistic Roman-Byzantine school of religious architecture [35].

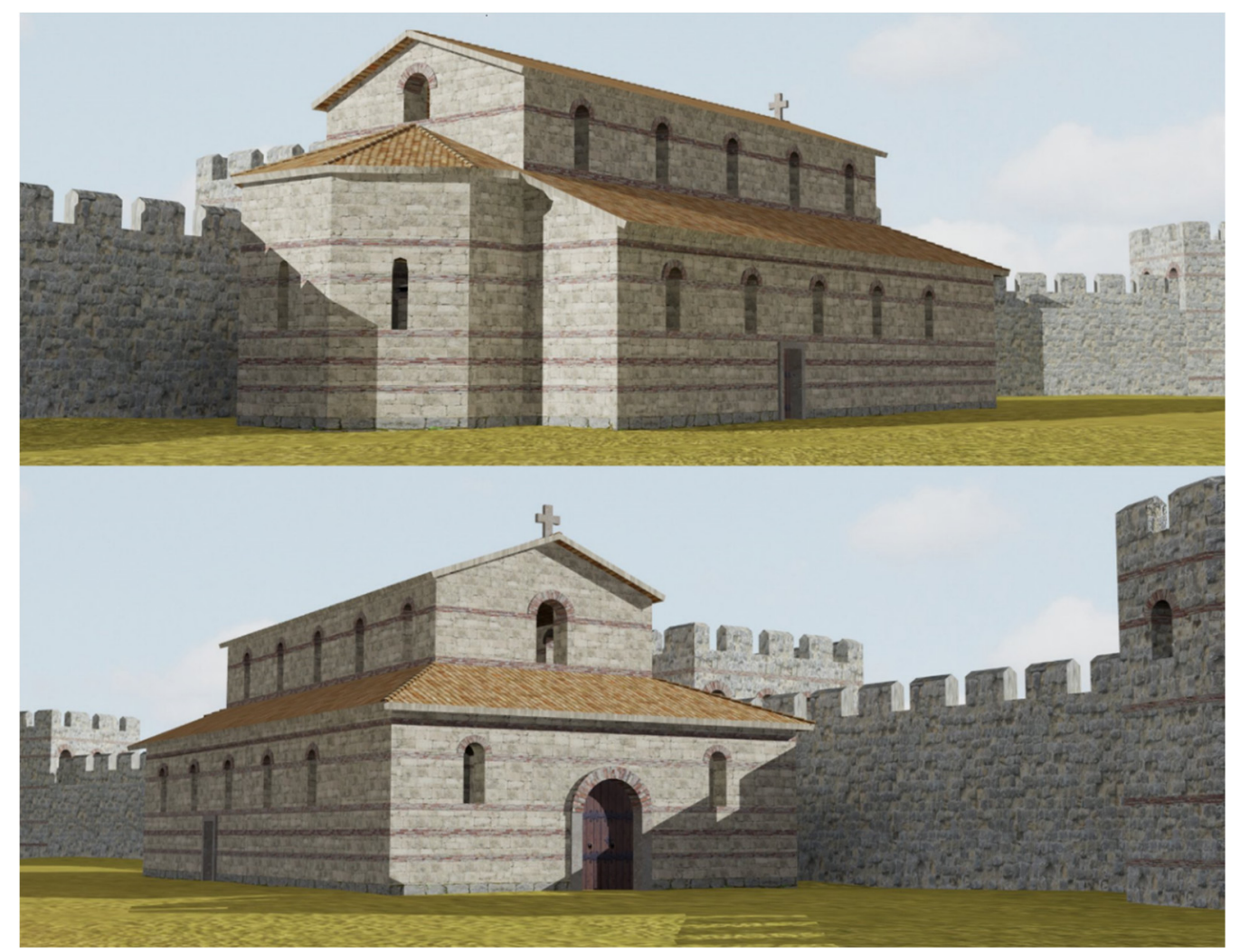

Figure 14. Reconstruction of the appearance of the Church No. 3.

During its reconstruction, we were guided both by analogies with churches of the same period and by description of its probable appearance, which was given by I.N. Tsitsishvili: "... one can imagine the Pitsunda Basilica in the form of a building with a high middle nave and a gable roof covered with tiles, lower side naves and a narthex, with lean-to roofs leaning against the main building. The multifaceted apse, apparently, had an independent pyramidal roof" [36].

At the end of the 4th-beginning of the 5th century, in the place of the Church No. 3, the Church No. 4 [37] was built. Its reconstruction has not yet been carried out because, firstly, it goes beyond the chronological framework of the reconstructed model of the fortress, and secondly, similar to Church No. 2, it is distinguished by its architectural originality, which requires additional investigation. Therefore, the reconstruction of its appearance is the task of future works.

\section{Conclusions}

The results presented are the first large-scale visualization of the appearance of the Roman fortress Pitiunt in the 4th century AD. Obviously, with the appearance of new archaeological data, the model of the fortress will be refined and supplemented. At this point, the reconstruction did not pursue a detailed study of the buildings, since there is no required archaeological material for doing so, but it was aimed at visualizing the general view of the fortress to convey the historical context in which the garrison of the fortress and the inhabitants of the eastern fortification canabas lived. The obtained results can be important in educational and museum work, since the site is in a serious state of disrepair, and the territory is overgrown with rough subtropical vegetation and is abandoned. Even many local residents do not know what overgrown stone wall is located in the very center 
of the city of Pitsunda. At the same time, not everyone can get to the territory of the unrecognized republic of Abkhazia and inspect the site for political reasons. Therefore, the use of visualization of this site next to the object via a billboard, and in more detail in the museums of the region using printed materials, video renders of flying around the fortress or immersion in virtual reality (VR), will demonstrate the prominence of this fortress in the historical picture of the Eastern Black Sea coast in the first centuries AD.

Author Contributions: G.T.-management of archaeological exploration and preparation of a publication; A.K.- preparation of drawings; K.G.--processing of 3-D models in programs and preparation of a publication; S.S. - work with archival materials; V.Y.-processing of 3-D models in programs; G.Y.-preparation of material on geological paleoreconstructions. All authors have read and agreed to the published version of the manuscript.

Funding: This research received no external funding.

Institutional Review Board Statement: Not applicable.

Informed Consent Statement: Not applicable.

Data Availability Statement: The data on the basis of which the study was conducted are presented in the references provided to the article.

Conflicts of Interest: The authors declare no conflict of interest.

\section{References}

1. Monterroso-Checa, A.; Redondo-Villa, A.; Gasparini, M.; Hornero, A.; Iraci, B.; Martín-Talaverano, R.; Moreno-Escribano, J.C.; Muñoz-Cádiz, J.; Murillo-Fragero, J.I.; Obregón-Romero, R.; et al. A heritage science workflow to preserve and narrate a rural archeological landscape using virtual reality: The cerro del castillo of belmez and its surrounding environment (Cordoba, Spain). Appl. Sci. 2020, 10, 8659. [CrossRef]

2. Gner, V.A. The use of a quadrocopter for aerial photography in archaeological research. Archeol. Geoinform. 2019, 9. Available online: https: / / www.archaeolog.ru/media/periodicals/agis/AGIS-9/Gnera/page1.html (accessed on 1 February 2021).

3. Zhukovsky, M.O. The Use of Multi-Rotor Uavs and Photogrammetric Technologies for Processing Aerial Photography in Modern Archaeological Research. In Proceedings of the Virtual Archeology, St. Petersburg, Russia, 1-3 June 2015; pp. 106-109. Available online: http:/ / www.virtualarchaeology.ru/pdf/281_va_book2015.pdf (accessed on 1 February 2021).

4. Logdacheva, E.V.; Schwemberger, S.V. Problems and methods of three-dimensional reconstruction. Multimedia information system. In Architecture and Wall Paintings of the Novgorod Church of the Transfiguration of the Savior on Neredits; St. Petersburg State University: St. Petersburg, Russia, 2009. Available online: http://nereditsa.ru/3D/article.htm (accessed on 1 February 2021).

5. Chernenko, E.A. 3D graphic reconstruction and visualization of the archeological monument. Inf. Soc. 2015, 2-3, 80-85. Available online: https: / / www.elibrary.ru/item.asp?id=25867200 (accessed on 1 February 2021).

6. Trebeleva, G.V.; Glazov, K.A.; Kizilov, A.S.; Sakania, S.M. Application of 3D-Photogrammetry of Archaeological Objects in Mountainous and Wooded Areas of the Western Caucasus. In Proceedings of the VI (XXII) All-Russian Archaeological Congress in Samara, Samara, Russia, 12-14 September 2020; Volume 3, pp. 178-180.

7. Trebeleva, G.V.; Sakania, S.M.; Glazov, K.A.; Kizilov, A.S.; Yurkov, G.Y. Late Antique and Medieval Temples of Abkhazia: GIS, Research Using Photogrammetry and Creation of 3D Models. In Proceedings of the Archeology and Geoinformatics. Fourth International Conference, Moscow, Russia, 21-23 May 2019; pp. 98-100.

8. Büyüksalih, G.; Kan, T.; Özkan, G.E.; Meriç, M.; Isın, L.; Kersten, T.P. Preserving the knowledge of the past through virtual visits: From 3D Laser scanning to virtual reality visualisation at the Istanbul Çatalca İnceğiz caves. PFG J. Photogramm. Remote Sens. Geoinf. Sci. 2020, 88, 133-146. [CrossRef]

9. Tschirschwitz, F.; Richerzhagen, C.; Przybilla, H.-J.; Kersten, T.P. Duisburg 1566: Transferring a historic 3D city model from google earth into a virtual reality application. PFG J. Photogramm. Remote Sens. Geoinf. Sci. 2019, 87, 47-56. [CrossRef]

10. Blanco, A.M.; Sánchez, J.G.; Costa-García, J.M.; Fonte, J.; González-Álvarez, D.; García, V.V. Following the Roman army between the southern foothills of the Cantabrian Mountains and the northern plains of Castile and León (north of Spain): Archaeological applications of remote sensing and geospatial tools. Geosciences 2020, 10, 485. [CrossRef]

11. Karelin, D.A.; Zhitpeleva, T.I.; Karelin, M.A. Some problems and features of creation of 3d-reconstructions of late Roman fortresses in Egypt. AMIT 2015, 3, 32. Available online: http:/ / www.marhi.ru/AMIT/2015/3kvart15/karelin/abstract.php (accessed on 1 February 2021).

12. Karelin, D.A.; Zhitpeleva, T.I.; Karelina, M.A. Visualization of the late Roman fortress-Reconstruction of the late Roman fortress in Dionysias (Egypt). AMIT 2015, 1. Available online: http://www.marhi.ru/AMIT/2015/1kvart15/karelin/abstract.php (accessed on 1 February 2021). 
13. Karelin, D.A. Roman Fortification Architecture in Egypt. 1st Century BC-V century AD. Ph.D. Thesis, Research Institute of the Theory and History of Fine Arts of the Russian Academy of Arts, Moscow, Russia, 2010. Available online: https: //new-disser.ru/_avtoreferats/01004652926.pdf (accessed on 1 February 2021).

14. Gregory, S. Roman Military Architecture on the Eastern Frontier; Adolf M. Hakkert: Amsterdam, The Netherlands, 1997.

15. Jaritz, H.; Mustafa, M. A Roman Fortress at Nag el-Hagar. Preliminary report. Am. Soc. Assoc. Exec. 1985, 70, 21-31.

16. Lain, A.; Parker, S.T. The Principia of el-Lejjūn (Area A). In The Roman Frontier in Central Jordan. Final Report on the Limes Arabicus Project 1980-1989 (Dumbarton Oaks Studies 40); Parker, S.T., Ed.; Dumbarton Oaks Research Library and Collection: Washington, DC, USA, 2006; Volume 1, pp. 123-160.

17. Lander, J. Roman Stone Fortifications. Variations and Change from First Century, A.D. to the Fourth; BAR: Oxford, UK, 1984.

18. De Vries, B.; Godwin, V.; Lain, A. The Fortifications of el-Lejjūn. In The Roman Frontier in Central Jordan. Final Report on the Limes Arabicus Project 1980-1989 (Dumbarton Oaks Studies 40); Parker, S.T., Ed.; Dumbarton Oaks Research Library and Collection: Washington, DC, USA, 2006; Volume 1, pp. 161-212.

19. Bernarda, Y.; Barreaua, J.-B.; Bizien-Jaglinb, C.; Quesnela, L.; Langouët, L.; Daire, M.-Y. 3D model as a dynamic compilation of knowledge: Interim results on the city of Alet. Virtual Archaeol. Rev. 2017, 8, 51-60. [CrossRef]

20. The London Charter for the Computer-Based Visualisation of Cultural Heritage. 2009. Available online: https://www. londoncharter.org/ (accessed on 1 February 2021).

21. Balabanov, I.P. Paleographic Preconditions for the Formation of Modern Natural Conditions and a Long-Term Forecast of the Development of Holocene Terraces on the Black Sea Coast of the Caucasus; Dalnauka: Moscow, Russia; Vladivostok, Russia, 2009 ; pp. 117-118.

22. Apakidze, A.M. Historical evidence. In Great Pitiunt. Archaeological Excavations in Pitsunda; Javakhishvili, I.A., Ed.; Metsniereba: Tbilisi, Georgia, 1978; Volume 3, p. 11.

23. López de Mota, J.G.C.; Valle, D.G. La arqueología de órdenes militares en castilla-la mancha y la reconstrucción virtual de supatrimonio. Virtual Archaeol. Rev. 2018, 9, 76-88. [CrossRef]

24. Agbunov, M.V. Antique Sailing Route of the Black Sea; Nauka: Moscow, Russia, 1987; pp. 73-75.

25. Kiguradze, N.S.; Lordkipanidze, G.A.; Todua, T.T. Hallmarks of the XV legion from the Pitsunda settlement. Bull. Anc. Hist. 1987, 2, 88-92.

26. Baatz, D. Eine Katapult-Spannbuchse aus Pityus, Georgien (UdSSR). Saalburg-Jahrbch 1988, 44, 59-64.

27. Apakidze, A.M. Archaeological work on the territory of the "Great Pitiunt". In Great Pitiunt. Archaeological Excavations in Pitsunda; Javakhishvili, I.A., Ed.; Figures 3-5; Metsniereba: Tbilisi, Georgia, 1975; Volume 1.

28. Trebeleva, G.V. The Great Abkhazian (Kelasur) Wall: Research Results; Print House: Moscow, Russia, 2019.

29. International Principles of Virtual Archaeology. The Seville Principles 2011. Available online: http://smartheritage.com/sevilleprinciples/seville-principles (accessed on 1 February 2021).

30. Resco, P.A.; Figueiredo, C. El grado de evidencia histórico-arqueológica de las reconstrucciones virtuales: Hacia una escala de representación gráfica - the level of historical-archaeological evidence of virtual reconstructions: Towards a scale of graphical representation. Revista Otarq Otras arqueologias. 2016, 1, 235-247. [CrossRef]

31. Gonio-Apsaros Fortress (Georgia). History and archeology of the settlement of Sarkel-Belaya Vezha. Available online: http: //sarkel.ru/istoriya/krepost_gonio-apsaros_gruziya (accessed on 1 February 2021).

32. Apakidze, A.M. Great Pitiunt. Archaeological Excavations in Pitsunda; Javakhishvili, I.A., Ed.; Metsniereba: Tbilisi, Georgia, 1978; Volume 3.

33. Apakidze, A.M. Results of 3D reconstruction of "Great Pitiunt". In Great Pitiunt. Archaeological Excavations in Pitsunda; Javakhishvili, I.A., Ed.; Metsniereba: Tbilisi, Georgia, 1978; Volume 3, p. 66.

34. Kiguradze, N.S.; Lordkipanidze, G.A.; Todua, T.T. Symbols of the XV legion from the Pitsunda settlement. Bull. Anc. Hist. 1987, 2, 88-92.

35. Trebeleva, G.V.; Sakania, S.M. Christian Churches of medieval Abkhazia. Gagra district. Humanit. Res. 2017, 7. Available online: http:/ / human.snauka.ru/2017/07/24230 (accessed on 1 February 2021).

36. Sakania, S.M.; Trebeleva, G.V. Late Antique and Medieval Christian Churches of the North-Eastern Black Sea Region. Catalog; CJSC Magnitogorsk House of Printing: Magnitogorsk, Russia, 2019; Volume 1, pp. 27-40.

37. Tsitsishvili, I.N. Great Pitiunt. Complex. of Church Buildings in Pitsunda; Javakhishvili, I.A., Ed.; Metsniereba: Tbilisi, Georgia, 1977; Volume 3, p. 118. 